\section{FORAGING RATES OF DIFFERENT APIS SPECIES VISITING PARENTAL LINES OF BRASSICA NAPUS L.}

\author{
Jasvir Singh", O.P. Agrawal and R.C. Mishra ${ }^{2}$ \\ Entomology Research Unit, School of Studies in Zoology, Jiwaji \\ University, Gwalior, Madhya Pradesh 474011, India \\ ${ }^{1}$ Street No. 12, Yog Nagar, BUDHLADA District Mansa, Punjab \\ 151502, India \\ 2 \# 337, Sector 4, Panchkulla 134112, India
}

Most of the insect pollinators of Brassica crops belong to Apis species. Foraging rate is one of the important factors to compare pollination efficiency of different bee species. In general, more the foraging frequency, more the chances of pollination. The number of flowers visited per minute by any bee species depends upon the number of factors including instinctive foraging behaviour, length of proboscis (Inouye, 1980) floral structure (Free, 1970) particularly the corolla depth (Gilbert, 1980) type and quantity of floral rewards (Rao \& Suryanarayana, 1990; Rao, 1991) density of flowers on particular cultivar of the crop concerned and hours of the day. The present paper reports the comparision of foraging rates of various honeybee species on parental lines of B. napus at different hours of the day.

Experimental plots ( $10.5 \times 1.5$ meter) were raised for hybrid seed production under Punjab conditions by using seeds of cytoplasmically male-sterile (CMS) line (TCMS-PR-05) and restorer (R) line (TFR-91) of B. napus hybrid PGSH-51, during year 1998-99, by following recommendations of Punjab Agricultural University, Ludhiana (Punjab). Selected ratio of male to female rows were $2: 4$. $\mathrm{R}$ line plants showed inflorescence about 15 days earlier than those of CMS line. In order to make the flowering synchronous in both the parental lines, early flowering plants were detopped. Foraging activity of $A$. dorsata was enough in the area selected for study because two colonies of this bee species were present in nearby area. Two hives of A. florea were procured from other places and transplanted at suitable places (piles of dried sticks arranged just like natural habitat) in the field. In order to compare foraging rates of four honeybee species, two colonies each of $A$. mellifera and $A$. cerana were managed. Number of flowers visited per minute by a particular bee was counted with the help of a stop watch. Four bees of each Apis species were observed at each of the four selected hours of day (1000, 1200, 1400 and 1600), on R and CMS lines separately. This experiment was conducted on alternating days during blooming time (40 days) of the crop. Data collected were consolidated, tabulated, transformed $(n+1$ transformation) and subjected to Analysis of Variance (ANOVA). Significance was tested at 5per cent level.

Number of flowers visited per minute by various bee species at different day hours, on R and CMS lines is shown in Table 1. On an average (Table 2), 20.922, 19.572, 15.048 and 7.712 flowers were visited per minute by $A$. cerana, A. mellifera, A. dorsata and $A$. florea respectively. Foraging rates of $A$. cerana and $A$. mellifera were not different statistically. Foragers of these two bee species visited significantly more number of flowers per unit time as compared to those of $A$. dorsata and $A$. florea. These finding are in line with the information given by Desh Raj and Rana (1994) about time spent per flower by A. mellifera and $A$. cerana on rapeseed (B. campestris var. brown sarson) bloom. Jhajj et al. (1996) also found the foraging frequency of various bee species as $A$. mellifera $>A$. dorsata $>A$. florea on raya and brown sarson.

On an average (Table 3) Apis species visited 15.612, 18.253, 15.326 and 14.062 flowers per minute at $1000 \mathrm{hr}, 1200 \mathrm{hr}, 1400 \mathrm{hr}$ and $1600 \mathrm{hr}$, respectively. Foraging rate was significantly more at $1200 \mathrm{hr}$. Number of flowers visited/min. by bees at $1000 \mathrm{hr}$, $1400 \mathrm{hr}$ and $1600 \mathrm{hr}$ did not differ statistically. Maximum foraging rate of bees during $1200-1300 \mathrm{hr}$ has also been reported by many workers on Brassica crops (Dhaliwal \& Bhalla, 1980; Desk Raj \& Rana, 1994; Anon, 1999). Maximum foraging rate of Apis species at 1200 on parental lines of B. napus as observed in present study might be due to the fact that supply of available floral rewards declined by this time due to decreased amount of nectar in flowers as observed by Meyerhoff (1954) in case of Swede rape and increased foraging activity of bees. So, less time was needed to take the forage from a flower and more flowers were visited by a bee to obtain required load of pollen or nectar. Thus hours of day seem to have played an important role in foraging rate of bees because floral rewards of parental lines and foraging activity of insect visitors are directly linked with them.

On an average (Table 4) foraging rate of Apis species was significantly more on CMS line (17.607 flowers/min) than that on $\mathrm{R}$ line (14.020 flowers/min.). These results are in line with finding of Mohr and Jay (1988), who observed that foraging frequency of honeybees on two different species of Canola $(B$. campestris L. and B. napus L.) was different.

$\mathrm{R}$ line flowers offer both nectar and pollen, hence bees visiting them were pollen and/or nectar gatherers, while the flowers of CMS line provided only nectar as they do not produce pollen, so foraging bees were only nectar gatherers. Therefore, honey bees spent more time on $\mathrm{R}$ line flowers for collection of nectar and pollen than that on CMS line for collection of nectar only. Similar type of conclusion was drawn by Adegas and Nogueira Couto (1992) that nectar collecting bees spent less time per flower as compared to pollen gatherers on B. napus L. var oleifera (Cultivar CTC-4).

Foraging rate is one of the important factors to determine pollination efficiency of any bee species. So, from this study it may be concluded that $A$. cerana and $A$. mellifera have statistically same foraging rate. Both of these bee species showed significantly higher foraging rate as compared to $A$. dorsata and $A$. florea. Significantly, lesser foraging frequency was recorded in case of $A$. florea. Foraging rate varied according to hours of the day and it was observed to be maximum at $1200 \mathrm{hr}$. Number of flowers visited per minute on CMS line was significantly higher in comparison to that on $\mathrm{R}$ line. 
Table 1. Number of flowers visited per minute by different Apis species on parental lines of B. napus at selected hours of day.

\begin{tabular}{|c|c|c|c|}
\hline Days Hours & Apis species & $\begin{array}{l}\text { Number of flow } \\
\text { R line }\end{array}$ & $\begin{array}{l}\text { rs visited/min. } \\
\text { CMS line }\end{array}$ \\
\hline $10 \mathrm{am}$ & $\begin{array}{l}\text { Apis mellifera } \\
\text { Apis cerana } \\
\text { Apis dorsata } \\
\text { Apis florea }\end{array}$ & $\begin{array}{l}17.666(4.299) \\
19.625(4.528) \\
12.5(3.674) \\
7(2.826)\end{array}$ & $\begin{array}{l}20.666(4.652) \\
22.5(4.846) \\
15.5(4.062) \\
9.440(3.224)\end{array}$ \\
\hline $12 \mathrm{pm}$ & $\begin{array}{l}\text { Apis mellifera } \\
\text { Apis cerana } \\
\text { Apis dorsata } \\
\text { Apis florea }\end{array}$ & $\begin{array}{l}20.904(4.672) \\
20.167(4.595) \\
15.8(4.098) \\
7.4(2.892)\end{array}$ & $\begin{array}{l}25.833(5.172) \\
28.583(5.438) \\
16.834(4.174) \\
10.5(3.381)\end{array}$ \\
\hline $14 \mathrm{pm}$ & $\begin{array}{l}\text { Apis mellifera } \\
\text { Apis cerana } \\
\text { Apis dorsata } \\
\text { Apis florea }\end{array}$ & $\begin{array}{l}16(4.108) \\
17(4.242) \\
14.75(3.964) \\
5(2.445)\end{array}$ & $\begin{array}{l}20(4.522) \\
24.5(4.999) \\
15.5(4.062) \\
9.857(3.282)\end{array}$ \\
\hline $16 \mathrm{pm}$ & $\begin{array}{l}\text { Apis mellifera } \\
\text { Apis cerana } \\
\text { Apis dorsata } \\
\text { Apis florea }\end{array}$ & $\begin{array}{l}15.5(4.062) \\
15.5(4.061) \\
15(3.999) \\
4.5(2.344)\end{array}$ & $\begin{array}{l}20(4.582) \\
19.5(4.488) \\
14.5(3.936) \\
8(2.998)\end{array}$ \\
\hline
\end{tabular}

Table 2. Foraging rates of different bee species irrespective of day hours and parental lines.

\begin{tabular}{lllll}
\hline Day hours & A. mellifera & A. cerana & A. dorsata & A. florea \\
\hline Number of flowers & 19.572 & 20.922 & 15.048 & 7.712 \\
Visited/min. by bees & $(4.508)$ & $(4.650)$ & $(3.996)$ & $(2.924)$ \\
\hline
\end{tabular}

Table 3. Foraging rates of Apis species irrespective of bee species and parental lines.

\begin{tabular}{|c|c|c|c|c|}
\hline Day hour & $10 \mathrm{am}$ & 12 pm & $2 \mathrm{pm}$ & $4 \mathrm{pm}$ \\
\hline $\begin{array}{l}\text { Number of flowers } \\
\text { Visited/min. by bees }\end{array}$ & $\begin{array}{l}15.612 \\
(4.014)\end{array}$ & $\begin{array}{l}18.253 \\
(4.302)\end{array}$ & $\begin{array}{l}15.326 \\
(3.953)\end{array}$ & $\begin{array}{l}14.062 \\
(3.809)\end{array}$ \\
\hline
\end{tabular}

Table 4. Number of flowers visited per minute by Apis species on $R$ and CMS lines irrespective of bee species and day hours.

\begin{tabular}{lll}
\hline Parental line & R line & CMS line \\
\hline Number of flower & 14.020 & 17.607 \\
visited/min. by bees & $(3.800)$ & $(4.238)$ \\
\hline
\end{tabular}

$\mathrm{CD}_{0.05}$

$\begin{array}{ll}\mathrm{F}_{0.05} & =0.167 \\ \text { For day hours } & =0.167 \\ \text { For Parental lines } & =0.118 \\ \text { For interaction day hours } \times \text { Apis spp. } & =\text { Non significant } \\ \text { For interaction day hours } \times \text { Parental lines } & =\text { Non significant } \\ \text { For interaction Apis spp. } \times \text { Parental lines } & =0.236 \\ \text { For interaction day hours } \times & \\ \text { Apis spp. x Parental lines } & =\text { Non significant } \\ \text { F value } & =11.8209 \\ \text { For day hours } & =168.2535 \\ \text { For Apis spp. } & =52.7422 \\ \text { For Parental lines } & \end{array}$

Figures in parenthesis are $\sqrt{\mathrm{n}+1}$ transformations.

\section{$\mathrm{F}$ value}

\section{REFERENCES}

Adegas, J.E.B and R.H. Nogueira Couto (1992). Entomophilous pollination in rape (Brassica napus L. var. oleifera) in Brazil. Apidologie 23: 203-209

Anonymous (1999). Annual report, All India coordinated Project on honeybee Res. and Trg. C.C.S, HAU Hissar, 16-20pp.

Desh, Raj and V.K. Rana (1994). Time spent by Apis mellifera L. and Apis cerana indica F. foragers on rapeseed bloom. Journal of Entomology Research 18: 335-339.

Dhaliwal, H.S. and O.P. Bhalla (1980). The foraging ecology of Apis cerana indica. Proceedings of the $2^{\text {nd }}$ International Conference Apic. Trop. Clim., New Delhi, 513-527pp.

Free, J.B. (1970). Insect pollination of crop plants. Academic Press, London and New York.

Gilbert, F.S. (1980). Flower visiting by hoverflies (syrphidae). Annual Revision of Ecological System 6: 139-170.

Inouye (1980). The effect of proboscis and corolla tube lengths on patterns and rates of flower visitation by bumble bees. Oecologia 45: 197-201.

Jhajj, H.S., G.S. Gatoria and D.R.C. Bakhetia (1996). Three decades of bee keeping research in the Punjab. Nat. Agric Tech. inf. Centre, Ludhiana (Punjab) 23-27pp.

Meyerhoff, G. (1954). Investigation on the effect of bee visits on rape. Arch. Geflügelz Kleintierk 3: 259-306.

Mohr, N.A. and S.C. Jay (1988). Nectar and Pollen collecting behaviour of honeybees on Canola (Brassica campestris L. and Brassica napus L.) Journal of Apiculture Research 27: 131-136.

Rao, G.M. (1991). Studies on the floral biology and pollination requirements of scented methi (Trigonella corniculata Linn.) Indian Bee Journal 53: 39-43.

Rao, G.M. and M.C. Suryanarayana (1990). Studies on the foraging behavior of honeybees and its effect on the seed yield in niger. Indian Bee Journal 52: 31-33. 